\title{
Onkolojide tercih edilen beslenme durumu tarama ve de ğerlendirme yöntemleri
}

\author{
Deniz KARPUZOĞLU*, Nazlı BATAR ${ }^{* *}$
}

\section{ÖZET}

Her geçen gün giderek artan kanser oranı önemli bir halk sağlığı sorunu haline gelmiştir. Kanser tedavisinde; kemoterapi, radyoterapi ve cerrahi yöntemler kullanılmaktadır. Tedavi yöntemleri, beslenme bozukluklarına yol açarak hastada malnütrisyon ve kaşeksinin görülmesine neden olabilmektedir. Bu yüzden kanser tedavi sürecinde tıbbi beslenme tedavisi ile bütüncül yaklaşımın gerekliliği artık tüm kanser kılavuzlarında yer almaktadır. Kanser tanısı alındığı andan itibaren tedavi süresince gerekli tarama-değerlendirme testlerinin yapılması malnütrisyon ve kaşeksi durumlarının önlenmesi için son derece önemlidir. Bu derlemede amaç, kanser hastalarında beslenme durumunu optimum düzeyde tutmak için hangi taramadeğerlendirme testlerine başvurmamız gerektiğini irdelemektir.

Anahtar sözcükler: Beslenme değerlendirmesi, beslenme durumu, kanser, malnütrisyon

\section{Preferred nutritional screening and assessment methods in oncology}

\begin{abstract}
The increase of the cancer rate has become an important public health problem. Chemotherapy, radiotherapy and surgical methods are used in cancer treatment. Treatment modalities cause nutritional deficiencies and trigger cachexia. Therefore, the need for a holistic approach to medical nutrition therapy in the cancer treatment process is now included in all cancer guidelines. From the moment the cancer is diagnosed, the necessary screening tests are essential for the prevention of malnutrition and cachexia. The aim of this review is to examine which screening tests should be performed to keep the nutritional status at the optimum level in cancer patients.
\end{abstract}

Keywords: Nutrition assessment, nutrition status, cancer, malnutrition

\footnotetext{
Geliş Tarihi: 20.05.2019 Kabul Tarihi:22.06.2019

* Acıbadem Üniversitesi, Sağlık Bilimleri Enstitüsü, Beslenme ve Diyetetik Ana Bilim Dalı, İstanbul, Türkiye,

e-posta: dytdenizkarpuzoglu@ gmail.com ORCID: 0000-0003-0746-8645

** İstanbul Kültür Üniversitesi, Sağlı Bilimleri Fakültesi, Beslenme ve Diyetetik Bölümü, İstanbul, Türkiye, e-posta: n.batar@iku.edu.tr ORCID: 0000-0001-9527-5709

Sorumlu Yazar/Correspondence: Deniz Karpuzoğlu ｅ-mail: dytdenizkarpuzoglu@gmail.com

Atıf: Karpuzoğlu D, Batar N. Onkolojide tercih edilen beslenme durumu tarama ve değerlendirme yöntemleri. Sağlık ve Yaşam Bilimleri Dergisi 2019;1(1):37-46.

Citation: Karpuzoglu D, Batar N. Preferred nutritional screening and assessment methods in oncology. Journal of Health and Life Science 2019;1(1):37-46.
} 


\section{GíRiş}

Beslenme bilimi; besin, yaşam, sağlık ve hastalık arasındaki etkileşimi tüm yönleriyle ele alır ve bir organizmanın besin maddelerinin tüketim, kullanım ve boşaltım süreçleriyle ilgilenir. ${ }^{1}$ Beslenme, yaşamda ve tıpta önemli bir rol oynar. Besin alımı ve artan katabolizma, çoğu akut ve kronik hastalıkların üzerinde belirgin etkiye sahiptir. Bu durum artan morbidite oranı ile beslenme arasında önemli bir ilişki kurmamızı sağlar. Diyet; diyabet, kardiyovasküler hastalıklar, bilişsel hastalıklar ve kanser gibi sorunların önlenmesi veya ertelenmesinin önemli bir belirleyicisidir. $^{2}$ Bireyi hedef alan, hastalıklara yönelik önleyici veya iyileştirici, herhangi bir beslenme önlemine klinik beslenme denir. Klinik beslenme; dislipidemi, tip 2 diyabet, obezite, kardiyovasküler hastalıklar, kanser, inme ya da kistik fibroz, gida alerjisi veya intoleransı gibi kronik hastalıkların tıbbi beslenme tedavisini içermektedir. ${ }^{3}$

$\mathrm{Bu}$ derlemede amaç, kanser hastalarında beslenme durumunu optimum düzeyde tutmak için hangi tarama-değerlendirme testlerine başvurmamız gerektiğini irdelemektir.

\section{Onkoloji Hastalarında Beslenme}

Kanser, hem gelişmekte olan hem de gelişmiş ülkelerde önemli bir ölüm sebebidir. Gelişen teknoloji ile hastalıkların erken teşhisi mümkün olabilmekte, erken müdahale ile mortalite azalmaktadır; fakat tedavi gören birçok kanser hastası, düşük besin alımı, duygusal stres ve tümörle ilişkili metabolik değişiklikler nedeniyle malnütrisyon ve ağırlık kaybı yaşar. Kanser hastalarının beslenme durumu, hastalığın prognozunun ve yaşam kalitesinin kritik bir belirleyicisidir. ${ }^{4}$ Kanser hastası; kanser teşhisi konmayı bekleyen, semptomatik tedavi ve/veya palyatif bakım alan, kanser teşhisi konmuş hastadır. Kanserden dolayı tedavi edilen hastalar 'kanser savaşçısı' olarak adlandırılmaktadır. ${ }^{5}$ Kanser tedavisinin neden olduğu olumsuz olaylar, malnütrisyona ve tedavi programında aksamaya sebep olabilmektedir. ${ }^{6}$

Cerrahi, kemoterapi ve radyasyon gibi kanser tedavi çeşitleri malnütrisyon ile ilişkilidir. Cerrahiye bağlı yan etkiler çoğunlukla kanserli dokunun cerrahi olarak çıkarılmasından kaynaklanmaktadır. ${ }^{7}$ En sık görülen yan etkiler ağız kanseri hastalarında çiğneme ve yutkunma zorluklarıdır. Baş- boyun kanserleri tanısı alan hastaların yaklaşık \%50'sinin ameliyat sonrası gıda alımında zorluk yaşadığı bildirilmiştir. ${ }^{8}$ Özofagus rezeksiyonu yapılan hastalarda disfaji, kısa bağırsak sendromu ve defekasyon artışına sıklıkla rastlanılırken; genel cerrahi kliniğinde kanser nedeniyle tedavi olan hastalarda hazımsızlık, reflü gibi mide sorunlukları ile karşılaşılmaktadır. ${ }^{9}$
Pankreas rezeksiyonu yapılan hastalarda ise hormonal ve enzimatik aktivitenin azalması nedeniyle besin emilimi azalabilmektedir. ${ }^{10}$

Kanser ilaçları çoğunlukla kusma, mukozit, ishal ve disfaji gibi yan etkilere sebep olur. ${ }^{11}$ Kanser ilacı tüketildikten sonraki 24 saat içinde, hastaların \%90'ından fazlasında mide bulantısı ve kusma şikayeti olur. ${ }^{12}$ Tedavi gören kanser hastalarında oral mukozit gelişebilir ve bu durum çiğneme ve yutma zorluklarına yol açar. Gastrointestinal kanser hastalarında, bağırsak mukoziti besin emilimini azaltır ve malnütrisyona yol açar. ${ }^{13}$ Radyasyon tedavisi de kemoterapi tedavisi gibi kusmaya neden olabilir. ${ }^{14}$

Malnütrisyon ve kas kütlesi kaybı kanser hastalarında sıklıkla görülür ve klinik sonuçlar üzerinde olumsuz etkiye sebep olur. Bu yüzden tüm kanser hastaları, malnütrisyon riski açısından düzenli olarak taranmalıdır. Kanserden kurtulanlar düzenli fiziksel aktiviteye başlamalı ve dikkatli bir diyet uygulamalidir. ${ }^{5}$

\section{Kanser ve Malnütrisyon}

Malnütrisyon, "Yetersiz besin alımından kaynaklanan azalmış yağsız vücut kütlesi ve azalmış vücut hücre kütlesine yol açan durum" olarak tanımlanmıştır. Fiziksel ve zihinsel fonksiyonların azalmasına ve hastalıklardan kaynaklanan klinik sonuçların bozulmasına neden olabilir. ${ }^{15}$ Malnütrisyon; uzun süreli açlık, hastalık veya ileri yaş ( $>80$ yaş) gibi birden fazla faktörün kombinasyonundan kaynaklanabilir. ${ }^{16}$

Sözel tanımların yetersiz kalmasından kaynaklı sorunların önüne geçmek için Avrupa Parenteral ve Enteral Nütrisyon (ESPEN) Kılavuzu, malnütrisyonun temel tanı kriterlerini belirlemiştir. Birinci tanımlama kriteri, beden kütle indeksinin (BKI) $18.5 \mathrm{~kg} / \mathrm{m}^{2}$ ' den düşük olmasıdır. İkinci alternatif tanı kriteri, istemsiz ağırlık kaybı ve düşük BKİ veya düşük yağsız vücut kütlesi (YVK) bulgusu gerektirir. $\mathrm{Bu}$ bulguyu tanımlamak için birden fazla alternatif vardır. Ağırlık kaybı, alışılmış ağırlığın \%10'undan veya son 3 aydaki ağırlığın \%5'inden fazla azalmış olmalıdır. Beden kütle indeksi 70 yaş altı kişilerde $20 \mathrm{~kg} / \mathrm{m}^{2}$ ' $n$ in; 70 yaş üstü kişilerde $22 \mathrm{~kg} / \mathrm{m}^{2}$ 'nin altına inmiş olmalıdır. Yağsız vücut kütlesi kadınlarda 15 $\mathrm{kg} / \mathrm{m}^{2}$ ' ${ }^{\prime}$; $;$ erkeklerde $17 \mathrm{~kg} / \mathrm{m}^{2}$ ' $\mathrm{nin}$ altında olmalidir. $^{17}$

Amerikan Parenteral ve Enteral Nütrisyon (ASPEN) Kilavuzu ve Beslenme ve Diyetetik Akademisi (AND) tarafindan belirtilen malnütrisyon durumunun potansiyel teşhisi için altı malnütrisyon kriterinin dikkate alınması gereklidir. Malnütrisyon teşhisi için düşük enerji alımı, ağırlık kaybı, kas kütlesi kaybı, 
deri altı yağ kaybı, sıvı birikimi ve el kavrama gücü değerlerinden en az iki kriterin karşılanması gerekir. ${ }^{18}$

Kanser Kaşeksisi: Hastalığa bağll yetersiz beslenme; sistemik inflamasyonun kanser gibi altta yatan bir hastalık tarafindan aktivasyonundan kaynaklanan bir durum olarak tanımlanmıştır. Enflamatuar yanıt, anoreksi ve doku parçalanmasına yol açar; bu da vücut ağırlığının kaybedilmesine, vücut bileşiminde değişikliklere ve fiziksel fonksiyonun azalmasına neden olabilir. ${ }^{17}$

Kaşeksi; konjestif kalp yetmezliği, enflamatuar bağırsak hastalıkları, kanser, kronik obstrüktif akciğer hastalığı $(\mathrm{KOAH})$, kronik böbrek hastalığı ve diğer son dönem organ hastalıklarını içeren katabolik enflamatuar yanttlarla komplike olan hastalarda s1k görülür. ${ }^{3}$ Kaşeksi, yağ kütlesi kaybı olsa da olmasa da devam eden iskelet kası kütlesi kaybı ve istemsiz ağırlık kaybı ile karakterize çok faktörlü bir durumdur. $\mathrm{Bu}$ durum standart beslenme bakımı ile geri döndürülemez ve işlevsel bozulmaya yol açabilir. ${ }^{19}$ Pre-kaşekside klinik ve metabolik belirtiler, istemsiz ağırlık ve kas kaybından önce fark edilir. Kaşeksi ve kaşeksinin ilerleme riski; kanserin türüne ve evresine, sistemik inflamasyonun derecesine ve kanser tedavisine tepki gibi birçok faktöre bağlıdır. ${ }^{19}$

\section{Kanser Hastalarında Tibbi Beslenme Tedavisi}

Kanser hastalarında beslenme desteği sınıflandırılmıştır:

1. Sağlıklı beslenme önerileri

2. Suni beslenme:

- Oral enteral beslenmeyle takviye

- Tüple enteral beslenme

- Parenteral beslenme

Beslenme biçiminin seçimi hastanın onkolojik tanısına, tedavi şekli ve dozuna, prognozuna ve beslenme durumuna bağlıdır. Besin alımı ve oral/enteral beslenme takviyesine rağmen yetersizse, enteral nutrisyon desteği, beklenen destek süresine ve hasta durumuna göre uygun görülen tüp tipi ve enteral ürün seçilerek başlatılır. Enteral nutrisyon yeterli veya mümkün değilse, parenteral nutrisyon önerilmektedir. ${ }^{5,20}$ Kanser hastalarında, malnütrisyon durumu olduğunda beslenme desteği, hastanın en az bir hafta boyunca yemek yiyemeyeceği veya besin alımının on günden fazla bir süre boyunca ihtiyaçlarının \%60'ından az olduğu durum olarak belirtilmektedir. ${ }^{5}$

Kanser hastalarının enerji gereksinimleri, kişiselleştirilmiş olarak (indirekt kalorimetre) yapılmazsa sağlıklı kişilerinkilere benzer (25-30 $\mathrm{kcal} / \mathrm{kg} / \mathrm{gün}$ ) olarak düşünülmelidir. ${ }^{5} \mathrm{Bu}$ yaklaşım ile yapılan enerji hesabı düşük BKI'li kişilerde yetersiz, yüksek BKİ'li kişilerde fazla olabilir. Harris-Benedict gibi denklemlerin kullanımı yeterli değildir. ${ }^{20}$
Gereksinimleri 1 (min. değer) ile 1.2-1.5 g/ $\mathrm{kg} /$ gün arasında olmalıdır. Protein katabolizması varsa 2 $\mathrm{g} / \mathrm{kg} / \mathrm{gün}$ 'e çıkarılabilir. Akut veya kronik böbrek yetmezliği olan hastalarda protein arzı sirasıyla 1 veya $1.2 \mathrm{~g} / \mathrm{kg} / \mathrm{gün}$ ü geçmemelidir. Enerji harcaması ile azot gereklilikleri arasında $100-130 \quad \mathrm{kcal} / \mathrm{g} \quad \mathrm{N}$ önerilir. ${ }^{21}$ İdeal lipit/karbonhidrat oranı, her hastanın patolojik öyküsü veya klinik durumu ile belirlenmelidir. ${ }^{21,22} \mathrm{Bu}$ oranın, artan glukoz oksidasyonu ve ağırlık kaybı nedeniyle, insülin direnci olması durumunda lipitler lehine kayması önerilebilir. ${ }^{22}$

Dikkate alınması gereken diğer bir konu ise peritoneal karsinomatozis durumunda tıkanıklık veya asit varsa, su ve sodyum ( $\mathrm{Su}$ için $30 \mathrm{ml} / \mathrm{kg} /$ gün, sodyum 1 $\mathrm{mmol} / \mathrm{kg} /$ gün) ihtiyaçları günlük tüketim limitini aşmamalıdır. ${ }^{5}$ Diğer bileşenlerle ilgili olarak, özellikle vitaminler ve iz elementlerin, spesifik bir tanım yoksa, önerilen günlük dozlardan daha yüksek miktarlarda takviye yapılması önerilmez. ${ }^{5}$

\section{ONKOLOJIDE BESLENME DURUMU TARAMA VE DEĞERLENDİRMESI}

Kanser hastalarında beslenme ve metabolik düzensizlikler sık görülür ve hastalığın prognozunda önemlidir. Beslenme riski taraması; farkındalı̆g artırmayı, erken tanı ve tedaviyi mümkün kılmayı amaçlar. Etkili olması için, taramaların kısa, ucuz ve yüksek derecede duyarlı olması gerekir. Bu amaçla BKİ (beden kütle indeksi), ağırlık kaybı ve besin alımı veya onaylanmış beslenme tarama araçları (Beslenme Riski Taraması 2002 [NRS-2002], Malnütrisyon Evrensel Tarama Aracı [MUST], Malnütrisyon Tarama Aracı [MST], Mini Beslenme Değerlendirmesi Kısa Form [MNA-SF]) ile hastanın değerlendirilmesi gerekmektedir. ${ }^{5}$

\section{Beslenme Durumu Saptanmasi}

Beslenme durumunun saptanmasını sağlayan tek bir parametre yoktur. Beslenme durumu saptanırken birkaç parametrenin kombinasyonundan bahsedilir. Tümörün yeri ve uygulanan tedavi gibi klinik parametreler belirlenmiştir. ${ }^{23}$ Mevcut semptomları ile hasta durumu hakkında sorgulanmalıdır. Ağırlık kaybı, besin alımını ve emilimini engelleyen riskler (Anoreksi, asteni, azalmış fiziksel aktivite, bulantı veya kusma, ishal, steatore veya kabızlık, disjesi, ağrı, depresyon veya yiyeceğe erişimi engelleyen sosyoekonomik problemler vb.) tespit edilmelidir. ${ }^{23}$

ESPEN kılavuzları, çift $\mathbf{X}$-ışını absorpsiyometrisi (DEXA) veya biyo-empedans analizi (BIA) ile gerçekleştirilebilecek kas ve yağ kütlesinin değerlendirmesini ve ayrıca ECOG, Karnofsky, dinamomeri vb. çeşitli ölçekler kullanarak fiziksel performansın değerlendirilmesini önermektedir. ${ }^{5}$

Beslenme durumuyla en fazla ilişkili olan biyokimyasal parametreler albümin ve prealbümindir. 
ESPEN kılavuzları, sistematik inflamasyonu ölçmek için serum C-reaktif protein (CRP) ve albümin kullanımını önermektedir. ${ }^{5}$ Antropometrik parametreler arasında, ağırlık kaybı, 6 ay boyunca $\% 10$ veya 3 boyunca $\% 5$, beslenme değerinin en güvenilir göstergesi olarak kabul edilir. ${ }^{23}$

\section{Beslenme Durumunun Taranmasi ve Tarama Araçları}

Beslenmenin değerlendirmesi, malnütrisyonun tanımlanmasında taramadan daha bilgilendiricidir, çünkü beslenme durumunun daha kapsamlı ve ayrıntılı bir değerlendirmesini sağlar. ${ }^{24} \mathrm{Bu}$ işlem zaman alıcıdır ve beslenme uzmanlığı ve eğitimi gerektirir. $\mathrm{Bu}$ nedenle tüm kanser hastalarında kullanım için pratik olmayabilir. ${ }^{25}$

Beslenme riski taraması, malnütrisyon riskindeki hastaları belirlemek için hızlı ve kolay bir işlemdir. ${ }^{26}$ Risk altında bulunanlar değerlendirmeye alınabilir. Doğrulanmış tarama araçlarının çoğu; mevcut ağırlık durumu, istemsiz ağırlık kaybı ve azalmış besin alımı gibi ana maddelerden oluşur. ${ }^{25}$

Malnütrisyonu tanımlamak için altın bir standardın ve evrensel olarak kabul görmüş bir beslenme bozukluğu tanımının olmaması hangi tarama aracının daha "doğru" bir sınıflandırma yaptığını belirlemeyi zorlaştırmaktadır. ${ }^{27}$ Çeşitli hasta grupları veya kanser hastaları için beslenme durumunu taramanın en iyi yolu konusunda uzmanlar arasında fikir birliği yoktur. ${ }^{28}$ Bununla birlikte, yaşlı kanser hastaları için uygun kabul edilen geçerli ve güvenilir beslenme tarama aracı mevcuttur. $\mathrm{Bu}$ araçlar arasında Malnütrisyon Tarama Aracı (MST) ${ }^{29}$ (Tablo 1), Mini Beslenme Değerlendirme Kisa Formu Gözden Geçirilmiş (MNA-SF) ${ }^{30}$ (Tablo 2) ve çoklu kullanım için geliştirilen Malnütrisyon Evrensel Tarama Aracı (MUST) $^{31}$ (Şekil 1) bulunmaktadır. Beslenme Riski Taramas1 2002 (NRS-2002) $^{32}$ (Tablo 3) hastane ortamında kullanılmak üzere geliştirilmiştir.

\section{a. Malnütrisyon Evrensel Tarama Aracı (MUST)}

MUST, çeşitli hasta ve ortam grupları için ilk tercih edilen tarama aracı olarak da önerilmiş olup birçok ülkede hastanelerde ve bakım evlerinde yaygın olarak kullanılmaktadır. ${ }^{33}$ Son üç ila altı aydaki ağırlık kaybı ve mevcut beden kütle indeksine dayanmaktadır. Ancak hastanede yatan hastalar söz konusu olduğunda ek bir bileşen vardır. "Akut" hastalık etkisi ve $>5$ gün boyunca diyet alımı olmaması durumunda skor artmaktadır. Malnütrisyon riski olan hastaları ve beslenme desteğine ihtiyaç duyanları tespit etmek amaçlanmıştır.

Tüm bakım ortamlarında kullanım için geliştirilmiştir ve bakımın bir ortamdan diğerine sürekliliğini kolaylaştırır. MUST içeren validasyon çalışmalarının çoğu, yaşlıları dahil etmiş ve bunların birçoğu hastanede yatan veya ayakta tedavi gören hastaları ve bakım evleri gibi ortamlarda bulunan kanser hastalarını içermektedir. Ayrıca kanser hastalarına özel olarak doğruluğu kanıtlanmıştır. ${ }^{34}$

\section{b. Beslenme Riski Taraması 2002 (NRS-2002)}

NRS-2002, mevcut malnütrisyon ile hastalık ciddiyetini ölçmek için tasarlanmıştır. Skorlama 0-6 arasında değişmekte olup, skoru $\geq 3$ tespit edilenlerde potansiyel beslenme müdahalesi için beslenme değerlendirmesi gerektirmektedir. NRS-2002, hastanede yatan hastalarda beslenme desteğinin kontrollü denemelerine karşı onaylanmıştır ve beslenme desteğinden fayda sağlayabilecek hastaları tanımlamaktadır. ${ }^{32}$

\section{c. Mini Beslenme Dĕgerlendirme Kısa Formu Gözden Geçirilmiş (MNA-SF)}

Rubenstein ve arkadaşları, 2001 yılında yaşlı yetişkinler için bir beslenme tarama aracı olarak kullanmak üzere, orijinal 18 maddeden tam MNA'dan altı maddeli MNA-SF'yi geliştirmiştir. ${ }^{30}$ MNA-SF; uygun müdahaleleri belirlemek için son zamanlardaki zayıf besin alımı, ağırlık kaybı, BKİ, hareketlilik, psikolojik stres veya akut hastalık ve nöropsikolojik problemleri irdeleyerek malnütrisyon riskine odaklanmaktadır. $^{35}$

\section{d. Malnütrisyon Tarama Aracı (MST)}

MST, son zamandaki istenmeyen ağırlık kaybı ve iştahsızlık nedeniyle yetersiz beslenme ile ilgili iki sorudan oluşmaktadır. MST, $\geq 2$ puan alırsa malnütrisyon riski olduğu düşünülen hastalarla 0-5 arasında bir puan sağlanır. ${ }^{29}$ MST doğrulanmıştır ve en basit beslenme tarama araçlarından biridir. İdari personel veya hasta tarafindan tamamlanabilir. MST, subjektif global göstergeler tarafindan belirlenen beslenme durumuyla ilişkili minimum parametreleri kullanarak beslenme riski altındaki hastaları tanımlamak için geliştirilmiştir.

\section{e. Subjektif Global Değerlendirme (SGA)}

Tarama araçları değişken bileşenlere sahiptir ve çoğunlukla Subjektif Global Değerlendirme'nin (SGA) (Tablo 4) altın standardıyla karşılaştırılmıştır. SGA değerlendirme alanına girer ve ağırlık kaybı ile azalmış fiziksel fonksiyonun yanı sıra kas ve yağ kütlesi kaybını ölçer. Fizik muayene gerektirir. SGA hastanede yatan hastada morbidite ve mortalite oranını tespit etmede etkili olmasına rağmen, bu testi uygulamak için gereken deneyimli profesyonel sayısı ve harcanan zaman diğer yaklaşımlardan daha fazladır. ${ }^{36}$ 
Genellikle klinisyenler tarafından kapsamlı bir beslenme değerlendirmesinin parçası olarak kullanılan araçlar arasında PG-SGA, SGA ve MNA bulunur. ${ }^{25}$ PG-SGA, kanser hastalarında performans durumundaki bilinen ağırlık kaybı göstergelerine ek olarak, besin alımının ve beslenme durumunun değerlendirilmesine olanak tanıyan ve buna sebep olan engellerin değerlendirildiği bir kombinasyona dayanmaktadır. ${ }^{37}$ SGA yaşlı erişkinlerde beslenme durumunu değerlendirmek için geçerli ve güvenilir bir araçtır. $^{38}$ SGA, hastanın tıbbi geçmişinden (Ağırlık kayb1, besin alımı, gastrointestinal semptomlar ve fonksiyonel kapasite) ve fiziksel muayeneden (Deri altı yă̆, kas kaybı ve ödem) oluşur. Hastalar iyi beslenmiş (A), orta derecede malnütrisyon (B) veya ciddi derecede malnütrisyon (C) olarak değerlendirilir. ${ }^{38}$

\section{SONUC}

Sonuç olarak, kanser tanı ve tedavi aşamalarında başarılı sonuçlar elde etmek için taramadeğerlendirme testlerinden faydalanmanın önemi birkaç sebep ile açıklanabilir. Birincisi taramadeğerlendirme testlerinin artırılması farkındalık sağlayarak erken teşhis ve tedavide ciddi bir önem taşır. İkinci olarak tarama-değerlendirme testlerini tercih ederken hangi amaç ve doğrultuda kullanıldığını doğru analiz ederek tercih etmek önemlidir. Beslenme durumunun saptanması ve kanser prognozu sürecinde cerrahi alanında deneyimli onkolog, diyetisyen ve hemşirenin dahil olduğu multidisipliner bir ekip oldukça önemlidir. Beslenme ilkeleri bu alanda uzmanlaşmış beslenme uzmanları tarafından 'nutrisyon eğitimi' adı altında düzenli periyotlarla tüm ekibe yapılmalıdır. Beslenme eğitimleri ile multidisipliner sağlık anlayışını benimseyerek hastaların tedavi süreçlerinin iyileştirilmesi ve hastanede kalış sürelerinin kısaltılması hedeflenmelidir.

\section{KAYNAKCA}

1. US national library of medicine national institute of health joint collection development policy: the national agricultural library, the national library of medicine, the library of congress. February 27, 1998. Updated October 14, 2014, http://www.nlm.nih.gov/pubs/cd_hum.nut.html\#2.

2. GBD 2013 Risk Factors Collaborators, Forouzanfar MH, Alexander L, et al. Global, regional, and national comparative risk assessment of 79 behavioral, environmental and occupational, and metabolic risks or clusters of risks in 188 countries, 1990-2013: a systematic analysis for the Global Burden of Disease Study 2013. Lancet 2015;386(10010):2287e323.

3. Lochs H, Allison SP, Meier R, et al. Introductory to the ESPEN Guidelines on Enteral Nutrition: terminology, definitions and general topics. Clin Nutr. 2006;25:180-6.
4. Caccialanza R, Pedrazzoli P, Cereda E, et al. Nutritional support in cancer patients: a position paper from the Italian Society of Medical Oncology (AIOM) and the Italian Society of Artificial Nutrition and Metabolism (SINPE). $J$ Cancer 2016;7:131-5.

5. Arends J, Bachmann P, Baracos V, et al. ESPEN guidelines on nutrition in cancer patients. Clin Nutr. 2017;36:11-48.

6. Kim JM, Sung M The efficacy of oral nutritional intervention in malnourished cancer patients: a systemic review. Clin Nutr Res. 2016; 5, 219-236.

7. Nicolini A, Ferrari P, Masoni MC, et al. Malnutrition, anorexia and cachexia in cancer patients: a mini-review on pathogenesis and treatment. Biomed Pharmacother. 2013;67:80717.

8. Zuydam AC, Lowe D, Brown JS, Vaughan ED, Rogers SN. Predictors of speech and swallowing function following primary surgery for oral and oropharyngeal cancer. Clin Otolaryngol. 2005;30:428-37.

9. Haverkort EB, Binnekade JM, Busch OR, van Berge Henegouwen MI, de Haan RJ, Gouma DJ. Presence and persistence of nutrition-related symptoms during the first year following esophagectomy with gastric tube reconstruction in clinically disease-free patients. World J Surg. 2010;34:2844-52.

10. Ryan AM, Healy LA, Power DG, Rowley SP, Reynolds JV. Short-term nutritional implications of total gastrectomy for malignancy, and the impact of parenteral nutritional support. Clin Nutr. 2007;26:718-27.

11. Dickens E, Ahmed S. Principles of cancer treatment by chemotherapy. Surgery 2018;36:1348.

12. Faria $\mathrm{C}, \mathrm{Li} \mathrm{X}, \mathrm{Nagl} \mathrm{N}, \mathrm{McBride}$ A. Outcomes associated with 5-HT3-RA therapy selection in patients with chemotherapy-induced nausea and vomiting: a retrospective claims analysis. $\mathrm{Am}$ Health Drug Benefits. 2014;7:50-8.

13. Santarpia L, Contaldo F, Pasanisi F. Nutritional screening and early treatment of malnutrition in cancer patients. J Cachexia Sarcopenia Muscle. 2011;2:27-35.

14. Maranzano E, De Angelis V, Pergolizzi S, et al; Di Gennaro DItalian Group for Antiemetic Research in Radiotherapy - IGARR. A prospective observational trial on emesis in radiotherapy: analysis of 1020 patients recruited in 45 Italian radiation oncology centres. Radiother Oncol. 2010;94:36-41.

15. Sobotka L, editor. Basics in clinical nutrition. 4th ed. Galen; 2012.

16. Pirlich M, Schütz T, Kemps M, et al. Social risk factors for hospital malnutrition. Nutrition 2005;21:295-300.

17. Cederholm T, Bosaeus I, Barazzoni R, et al. Diagnostic criteria for malnutrition - an ESPEN consensus statement. Clin Nutr. 2015;34:335-40.

18. White JV, Guenter P, Jensen G, Malone A, Schofield M. Consensus statement: Academy of Nutrition and Dietetics and American Society for Parenteral and Enteral Nutrition: characteristics recommended for the identification and documentation of adult malnutrition 
(undernutrition). JPEN J Parenter Enter Nutr. 2012;36:275-83

19. Fearon K, Strasser F, Anker SD, et al. Definition and classification of cancer cachexia: an international consensus. Lancet Oncol. 2011;12(5):489-95.

20. August DA. Huhmann MB; American Society for Parenteral and Enteral Nutrition (A.S.P.E.N.) Board of Directors. A.S.P.E.N. clinical guidelines: nutrition support therapy during adult anticancer treatment and in hematopoietic cell transplantation. JPEN $J$ Parenter Enter Nutr. 2009;33(5):472-500.

21. Bozzetti F, von Meyenfeldt MF. Nutrition support in different clinical situations: nutrition support in cancer patients. In: Lubos S, editor. Basics in clinical nutrition. 4th ed. Prague: ESPEN, GALEN; 2011. p. 573-83.

22. Planas M, Fernández-Ortega JF, Abilés J; Spanish Society of Intensive Care Medicine and Coronary Units-Spanish Society of Parenteral and Enteral Nutrition (SEMICYUC-SENPE). Update. SEMICYUC-SENPE consensus: oncohematological patient. Med Intensiva. 2011;35(Supl 1):53-6.

23. Virizuela JA, Camblor-Alvarez M, Uengo-Perez LM, Grande E, Álvarez-Hernández J, SendrósMadroño MJ. Nutritional support and parenteral nutrition in cancer patients: an expert consensus report. Clin Trans Oncol. 2018;20(5):619-29.

24. Skipper A, Ferguson M, Thompson K, et al: Nutrition screening tools: an analysis of the evidence. JPEN J Parenter Enteral Nutr. 36:2928, 2012. doi: $10.1177 / 0148607111414023$

25. Isenring E, Cross G, Kellett E, et al:Nutritional status and information needs of medical oncology patients receiving treatment at an Australian public hospital. Nutr Cancer. 62:220-8,2010. doi:10.1080/01635580903305276

26. Evidence based practice guidelines for the nutritional management of malnutrition in adult patients across the continuum of care. Nutrition \& Dietetics 66:S1-S34, 2009. doi:10.1111/j.17470080.2009.01383.x

27. Elia M, Stratton RJ. An analytic appraisal of nutrition screening tools supported by original data with particular reference to age. Nutrition 28:477-94, 2012. doi:10.1016/j.nut.2011.11.009

28. Bozzetti F, Mariani L, Lo Vullo S, et al. The nutritional risk in oncology: a study of 1,453 cancer outpatients. Support Care Cancer 20:191928, 2012. doi:10.1007/s00520-012-1387-x

29. Ferguson M, Capra S, Bauer J, et al. Development of a valid and reliable malnutrition screening tool for adult acute hospital patients. Nutrition 15:45864, 1999.

30. Rubenstein LZ, Harker JO, Salva A, et al. Screening for undernutrition in geriatric practice: developing the short-form mini-nutritional assessment (MNA-SF). J Gerontol A Biol Sci Med Sci. 56:M366-72, 2001.

31. Elia M. The 'MUST' report. Nutritional screening for adults: a multidisciplinary responsibility. Development and use of the 'Malnutrition Universal Screening Tool' ('MUST') for adults., A report by the Malnutrition Advisory Group of the British Association for Parenteral and Enteral Nutrition. ISBN 1899467 70X, 2003.

32. Kondrup J, Rasmussen HH, Hamberg O, et al. Nutritional risk screening (NRS 2002): a new method based on an analysis of controlled clinical trials. Clin Nutr. 22:321-36, 2003.

33. Russell CA, Elia M. Nutrition Screening Survey in the UK and Republic of Ireland in 2010, A report by British Association for Parenteral and Enteral Nutrition, 2011.

34. Boleo-Tome C, Monteiro-Grillo I, Camilo M, et al. Validation of the Malnutrition Universal Screening Tool (MUST) in cancer. $\underline{B r \quad J}$ Nutr. 108:343-8, doi:10.1017/S000711451100571X

35. Guigoz Y, Vellas B, Garry PJ. Assessing the nutritional status of the elderly: The Mini Nutritional Assessment as part of the geriatric evaluation. Nutr Rev. 54:S59-65, 1996.

36. Jensen GL, Compher C, Sullivan DH, Mullin GE. Recognizing malnutrition in adults: definitions and characteristics, screening, assessment, and team approach. JPEN J Parenter Enteral Nutr. 2013; 37: 802-7.

37. Ottery F. Patient-Generated Subjective Global Assessment, in McCallum P, Polisena C (eds): The Clinical Guide to Oncology Nutrition. Chicago, The American Dietetic Association, 2000, pp 11-23.

38. Detsky AS, McLaughlin JR, Baker JP, et al: What is subjective global assessment of nutritional status? JPEN J Parenter Enteral Nutr. 11:8-13, 1987. 
Tablo 1. Malnütrisyon tarama aracı (MST)

1.Yakın zamanda istemeden kilo verdiniz mi?

Hayır

0

Emin değilim

2

2.Cevabınız evet ise, kaç kilo kaybettiniz?

$1-5$

6-10

$11-15$

$>15$

Emin değilim

3.İştahsızlık sebebiyle kötü mü beslendiniz?

Hayır

0

Evet

1

Toplam

Toplam puanın 2 ve üzeri olması durumunda hasta yüksek malnütrisyon riski altındadır.

Tablo 2. Mini Beslenme Değerlendirme Kısa Formu Gözden Geçirilmiş (MNA-SF)

Tarama

\begin{tabular}{|c|c|}
\hline $\mathbf{A}$ & $\begin{array}{l}\text { Son üç ayda iştahsızlığa, sindirim sorunlarına, çiğneme veya yutma zorluklarına bağlı olarak besin alımında } \\
\text { bir azalma oldu mu? } \\
0=\text { besin alımında şiddetli düşüş } \\
1=\text { besin alımında orta derece düşu̧ş } \quad 2=\text { besin alımında düşüş yok }\end{array}$ \\
\hline B & $\begin{array}{l}\text { Son üç ay içindeki kilo kaybı durumu } \\
0=3 \mathrm{~kg} \text { 'dan fazla kilo kaybı } 1=\text { Bilinmiyor } \\
2=1-3 \mathrm{~kg} \text { arasında kilo kaybı } \\
3=\text { Kilo kaybı yok }\end{array}$ \\
\hline $\mathbf{C}$ & $\begin{array}{l}\text { Hareketlilik } \\
0=\text { Yatak veya sandalyeye bağımlı } \\
1 \text { = Yataktan, sandalyeden kalkabiliyor ama evden dışarıya çıkamıyor } \\
2 \text { = Evden dışarı çıkabiliyor }\end{array}$ \\
\hline D & $\begin{array}{l}\text { Son üç ayda psikolojik stres veya akut hastalık şikayeti } \\
\text { oldu mu? } \\
0=\text { Evet } 2 \text { = Hayır }\end{array}$ \\
\hline $\mathbf{E}$ & $\begin{array}{l}\text { Nöropsikolojik problemler } \\
0=\text { Ciddi bunama veya depresyon } 1=\text { Hafif düzeyde bunama } \\
2=\text { Hiçbir psikolojik problem yok }\end{array}$ \\
\hline F1 & $\begin{array}{l}\text { Beden Kitle İndeksi (BKİ) = (Vücut ağırlığl-kg) / }\left(\mathbf{B o y}^{2}\right) \\
0=\text { BKİ 19'dan az (19 dahil değil) } \\
1=\text { BKİ 19'la } 21 \text { arası }(21 \text { dahil değil }) \\
2=\text { BKİ 21'le } 23 \text { aras1 }(23 \text { dahil değil }) \\
3=\text { BKİ } 23 \text { ve üzeri }\end{array}$ \\
\hline F2 & $\begin{array}{l}\text { Baldır çevresi }(\mathbf{c m}) \\
\begin{aligned} 0 & =31 \text { 'den az } \\
1 & =31 \text { veya daha fazla }\end{aligned}\end{array}$ \\
\hline \multicolumn{2}{|c|}{ Değerlendirme } \\
\hline $\begin{array}{l}\text { Tarame } \\
12-14 \mathrm{p} \\
8-11 \mathrm{pr} \\
0-7 \mathrm{puc}\end{array}$ & $\begin{array}{lll}\text { puanı (0-14 puan) } & \\
\text { luan: } & \square \quad \begin{array}{l}\text { Normal nütrisyonel durum } \\
\text { Ian: }\end{array} \\
\text { n: } & \square & \begin{array}{l}\text { Malnütrisyon riski altında } \\
\text { Malnütrisyonlu }\end{array}\end{array}$ \\
\hline
\end{tabular}


Tablo 3. Beslenme Riski Taraması 2002 (NRS-2002)

\begin{tabular}{|l|l|l|}
\hline & Evet & Hayır \\
\hline Beden Kitle İndeksi $20.5 \mathrm{~kg} / \mathrm{m}^{2}$ den küçük mü? & & \\
\hline Son 3 ay içinde kilo kaybı var mı? & & \\
\hline Geçen hafta içinde besin alımında azalma var mı? & & \\
\hline Şiddetli bir hastalık var mı? & & \\
\hline
\end{tabular}

Eğer herhangi bir sorunun yanıtı evet ise, Tablo 2'ye geçilir. Tamamı hayır ise, hasta her hafta taranır. Majör operasyon yapılacaksa, olası risk durumlarına karşı önlem niteliğinde bir nütrisyon tedavi planı geliştirilir.

\begin{tabular}{|c|c|c|c|}
\hline \multicolumn{4}{|l|}{ Tarama } \\
\hline \multicolumn{2}{|c|}{ Nütrisyon Durumundaki Bozulma } & \multicolumn{2}{|c|}{ Hastalığın Şiddeti (gereksinimlerde artış) } \\
\hline $\begin{array}{l}\text { Yok } \\
\text { Skor } 0\end{array}$ & Normal nütrisyon durumu & $\begin{array}{l}\text { Yok } \\
\text { Skor } 0\end{array}$ & Normal besinsel gereksinimler \\
\hline $\begin{array}{l}\text { Hafif } \\
\text { Skor } 1\end{array}$ & $\begin{array}{l}3 \text { ayda }>\% 5 \text { kilo kaybı ya da geçen haftaki besin } \\
\text { alımı normal gereksinimlerin \%50-75'inin } \\
\text { altında }\end{array}$ & $\begin{array}{l}\text { Hafif } \\
\text { Skor } 1\end{array}$ & $\begin{array}{l}\text { Kalça Kemiğinde Kırık* Özellikle akut } \\
\text { komplikasyonları olan kronik hastalar: siroz*, } \\
\text { KOAH*, kronik hemodiyaliz, diabet, onkoloji }\end{array}$ \\
\hline $\begin{array}{l}\text { Orta Skor } \\
\mathbf{2}\end{array}$ & $\begin{array}{l}2 \text { ayda }>\% 5 \text { kilo kaybı ya da BKİ } 18.5-20.5+ \\
\text { genel durum bozukluğu ya da geçen haftaki } \\
\text { besin alımı normal gereksinimlerin } \% 25-50 \text { si }\end{array}$ & $\begin{array}{l}\text { Orta } \\
\text { Skor } 2\end{array}$ & $\begin{array}{l}\text { Majör abdominal cerrahi*, İnme*, Şiddetli } \\
\text { pnömoni, hematolojik malignite }\end{array}$ \\
\hline $\begin{array}{l}\text { Şiddetli } \\
\text { Skor } 3\end{array}$ & $\begin{array}{l}1 \text { ayda }>\% 5 \text { kilo kaybı }(3 \text { ayda }>\% 15) \text { ya da } \\
\text { BKİ }<18.5+\text { genel durum bozukluğu ya da } \\
\text { geçen haftaki besin alımı normal } \\
\text { gereksinimlerin } \% 0-25 \text { 'i }\end{array}$ & $\begin{array}{l}\text { Şiddetli } \\
\text { Skor } 3\end{array}$ & $\begin{array}{l}\text { Kafa travması*, Kemik iliği } \\
\text { transplantasyonu*, Yoğun Bakım hastaları } \\
(A P A C H E>10)\end{array}$ \\
\hline Skor: & + & Skor & $=$ Toplam skor \\
\hline Yaş & $\geq 70$ yaş ise toplam skora 1 ekle & \multicolumn{2}{|c|}{ = yaşa uyarlanmış toplam skor } \\
\hline
\end{tabular}

klinik çalışmalara dayanmaktadır. *işaretli tanısı olan hastaların

kategorizasyonunu doğrudan destekleyen bir çalışma var.

İtalik gösterilen tanılar yanda verilen prototiplere

dayanmaktadir.

Nütrisyon riski, o andaki nütrisyon durumu ve bunun stres metabolizması nedeniyle artan gereksinimlere bağlı olarak bozulması riski şeklinde tanımlanır.
(1) şiddetli malnütrisyonda (skor = 3), ya da (2) ağır hasta (skor = 3) ya da (3) orta derecede malnütrisyon + hafif hasta (skor $2+1$ ) ya da (4) hafif malnütrisyon + orta derecede hasta (skor 1+2)

Hastalığın derecesine ilişkin prototipler:

Skor=1: kronik hastalığ 1 olup komplikasyonlar nedeniyle hastaneye yatan bir hasta. Halsiz - düşkün durumdadır ancak düzenli olarak yataktan kalkabilir. Protein gereksinimleri artmıştır ancak oral diyet ya da suplemanlarla karşılanabilir.

Skor=2: majör abdominal cerrahi gibi bir hastalık nedeniyle yatağa bağlı bir hasta. Protein gereksinimleri yüksek, klinik beslenme yöntemleri gerekli ve bu sayede açıkları kapatılabiliyor

Skor=3: ventilasyon desteği altındaki yoğun bakım hastası. Protein gereksinimleri yüksek ve klinik beslenme yöntemleriyle karşılanamıyor. Protein yıkımı ve azot kaybı giderilebiliyor. 
Tablo 4. Subjektif Global Değerlendirme (SGA)

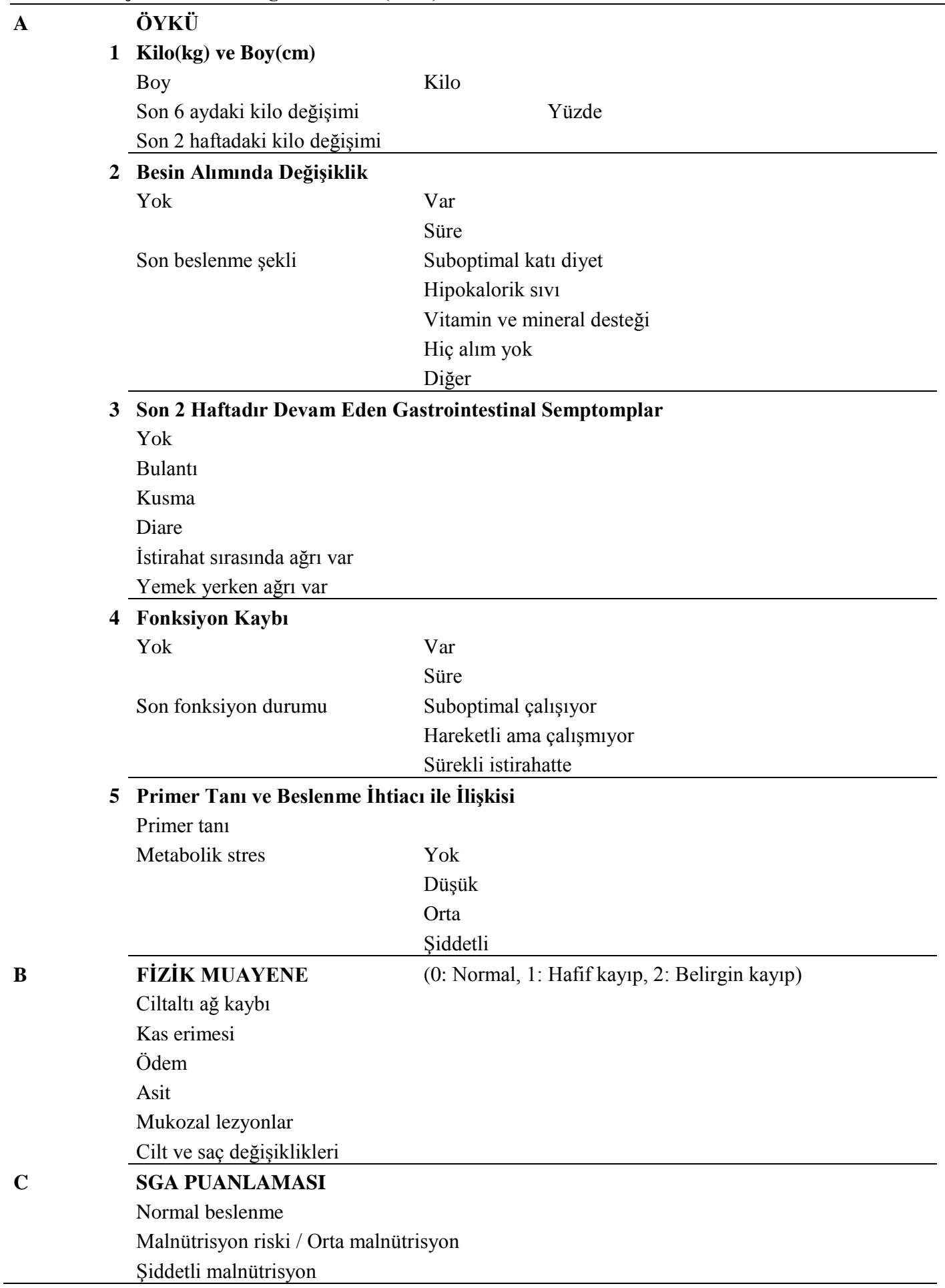


Şekil 1. Malnütrisyon Evrensel Tarama Aracı (MUST)

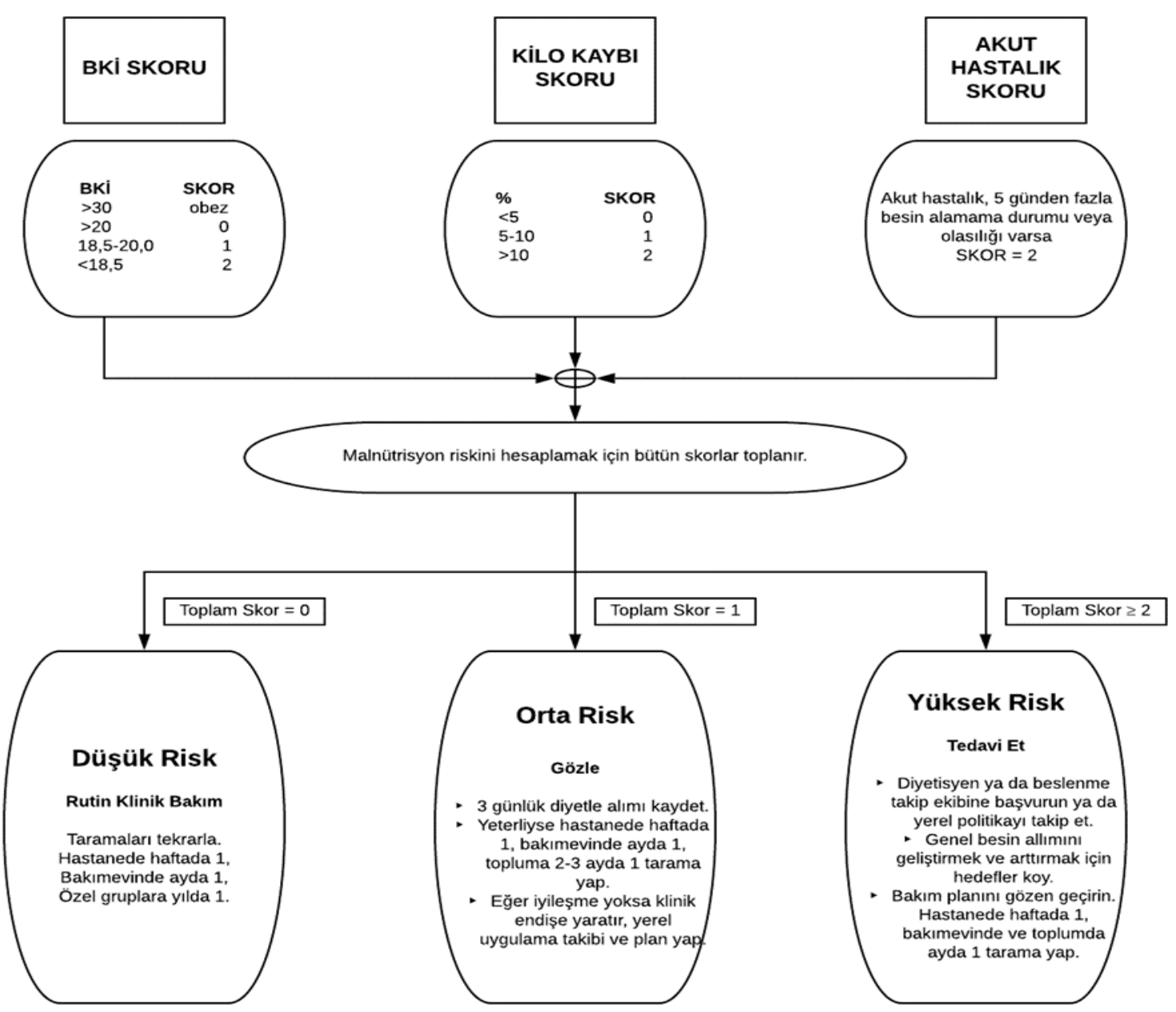

